\title{
Karikatüre Dayalı Öğrenme- Öğretme Modelinin Okul Öncesi Öğrencilerin Konuşma ve Dinleme Becerilerine Etkisi ${ }^{1}$
}

\author{
Dr. Sevda KOÇ AKRAN (Öğretim Üyesi) \\ Sürt Üniversitesi-Türkiye \\ sevdakc@gmail.com
}

\author{
Inci $\operatorname{KOCAMAN(YL)}$ \\ Siirt Üniversitesi-Türkiye \\ inci_ttanesi@hotmail.com
}

\begin{abstract}
Özet:
Bu araştırmanın temel amacı, karikatüre dayalı öğrenme- ögretme modelinin okul öncesi öğrencilerin konuşma ve dinleme becerilerine etkisini belirlemektir. Baskındaha az baskın karma yöntem desenin kullanıldı̆̆ araştırmada amaçsal örnekleme yöntemlerinden ölçüt örnekleme yöntemi kullanılmıştır. Araştırmanın çalışma grubuna Araştırmacılar tarafından geliştirilen yarı yapılandırımış görüşme formu ve gözlem formu uygulanmıştır. Verilerin analizinde konuşma ve dinleme becerilerine ilişkin hazırlanan gözlem formunda yer alan maddelerin normal dağılım gösterip göstermeme durumu için Shapiro-Wilks değerine bakılmıştır. Normallik testleri doğrultusunda gözlem formundaki maddelerin normal dağılım göstermediği görülmüştür. Konuşma ve dinleme becerileri ile ilgili hazırlanan gözlem formunda deney ve kontrol grubundaki ögrencilerin puanlarını karşılaştırmak için Mann Whitney U-Testi, grupların kendi içindeki ön test - son test puanlarını karşılaştırmak için ise Wilcoxon Iş̧aretli Sıralar Testi uygulanmıştır. Yarı yapılandırılmış görüşme formundan elde edilen veriler içinde betimsel ve içerik analizi yöntemi kullanılmıştır. Karikatüre dayalı öğrenme-öğretme modeli etkinlikleri ile ögrencilerin arkadaşlarının etkinliklerini ve açıklamalarını dikkatlice dinledikleri, anlamadıkları ve merak ettikleri konular hakkında sorular sordukları sonucuna ulaşılmıştır.
\end{abstract}

Keywords: Karikatür, Karikatüre dayalı öğrenme-öğretme modeli, Konuşma ve Dinleme becerisi.

DOI: 10.19160/ijer.384847

Gönderim : 27.01.2018 Kabul :23.07.2018

\section{Önerilen Atıf}

Koç Akran, S. \&. Kocaman, İ. (2018). Karikatüre Dayalı Öğrenme- Öğretme Modelinin Okul Öncesi Öğrencilerin Konuşma Ve Dinleme Becerilerine Etkisi, E-Uluslararası Eğitim Araştırmaları Dergisi, Cilt: 9, Sayı: 2, 2018, ss. 105-122, DOI: 10.19160/ijer.384847

\footnotetext{
15. Uluslararası Eğitim Programları ve Öğretim Kongresi," Temel Eğitimde Program Çalışmalarında sözlü bildiri olarak sunulmuştur. Muğla Sıtkı Koçman Üniversitesi Eğitim Fakültesi, 26-28, Ekim 2017, Muğla.
} 


\section{Giriş}

Karikatür, gazetelerde, dergilerde, televizyonda, reklam afişlerinde, vs. gülünüp geçilen, tartışılan düşünülen, eğlenmeyi, hicivi, görselliği içeren bir sanat ve iletişim aracıdır. Yani karikatür; hem çizgi hem de de mizah yapma sanatıdır (ilikçi, 2003; Özer, 2007). Çocukların dünyayı anlaması ve keşfetmesinde önemli bir kaynak olarak görülmektedir. Çünkü çocuklar okula başlamadan önce okuma ve yazmayı bilmemektedir. Okuma ve yazmayı bilmeyen çocuk, sayfalarca yazılan bir konuyu bir karikatürle kısa sürede öğrenebilmektedir. Bu yüzden karikatürlerin, başta çocukların öğrenmesi üzerinde önemli bir etkiye sahip olduğu söylenebilir (Uğurel ve Moralı, 2006). Toprakcı (2017) "karikatür"ü öğrenme ve öğretmenin yöntem ve teknikleri arasında saymıştır.

Karikatür, "öğrenmeyi öğrenme" yolunda çocukların öğretmeni gibidir (Çakır ve Aydoğdu, 2016). Karikatürle, olaylar çocukların zihinde daha kolay canlanmakta ve daha hızlı bir süreçte kodlanmaktadır. Anlamalı kodlamalar, çocukların üst düzey becerilere (eleştirel, problem çözme, yansıtıcı düşünme vb.) sahip olmasını sağlamaktadır (Seçkin Yalvac ve Çetin, 2013). Bilgileri örgütleme, anlamlandırma ve ilişkilendirmede etkili olduğu görülen karikatür ve çeşitlerinin eğitimde kullanılması gerekmektedir (Çetin, 2012). Örneğin kavram karikatürleri çocukların konuşma becerilerine, şemasındaki görsel bilgisini farklı bilgilerle ilişkilendirmesine yardımcı olmaktadır. Çocuklar, bu karikatürle öğrendiği bilgi ve beceriyi günlük yaşama daha kolay transfer etmektedir (Keogh, Naylor ve Wilson, 1998; Bing ve Tam, 2003). Aynı zamanda çocukların olaylar üzerinde tartışmasını sağlamaktadır (Kabapınar, 2005). Çocukların sınıf içinde yapılan etkinliklere/uygulamalara aktif katılmasını sağlayan bu karikatürlerin öğrenme-öğretme sürecinde kısa metinler şeklinde verilmesi önerilmektedir (Keogh, Naylor ve Wilson, 1998). Bunun sebepleri arasında, çocukların bilgileri küçük parçalardan büyük parçalara doğru yapılandırdığı, somuttan soyut bilgilere geçildiği, bilimsel bilgilere zamanla ulaştıkları ve bunu günlük yaşama transfer ettiği vb. gösterilmektedir (Evrekli ve İnel, 2008). Kısaca karikatüre dayalı yapılan bir öğrenme, çocukların hayata farklı bakış açılarla yaklaşmasını sağlamaktadır. Çocukların merak ve keşfetme duygusunu artırmaktadır. Çocuklar bu öğrenme yoluyla, kendisini ve yakın çevresini eleştirmektedir. Gerçek yaşamın problemleriyle karşılaşmaktadır. Problemlere bazen eğlenerek bazen gülerek çözüm bulmaya çalışmaktadır (Eulie, 1969; Stephenson ve Warwick, 2002; Coll, 2005; İngeç, Yıldız ve Ünlü, 2006; Kleeman, 2006; Ersoy ve Türkkan, 2010).

Karikatür ve karikatüre dayalı öğrenme sürecinin bireyler üzerindeki etkisi/katkısı yukardaki açıklamalarla sınırlı değildir. Yapılan birçok araştırmada bu etkileri görmek mümkündür. Mesela yapılan araştırmalarda karikatürlerin dil becerilerine (Keogh, ve Naylor, 1999; Rule ve Auge 2005; Morris, Merritt, Fairclough, Birrell, ve Howitt, 2007; Hakam, 2009), Türk Dili ve Edebiyatı dersi yazııı anlatım becerisi (Üstün, 2007), sosyal bilgilerin öğretimine (Gökkaya, 2006), tarih (Köseoğlu, 2008), fen (Balım, İnel ve Evrekli, 2008; Oluk ve Özalp, 2007) ve matematik eğitimine (Uğurel ve Moralı, 2006) ilişkin çalışmaların olduğu görülmüştür. Ancak karikatürle ilgili yapılan yurt içindeki ve yurt dışındaki yapılan araştırmalarda karikatürün okul öncesinde ve temel dil becerilerinden konuşma ve dinleme üzerindeki etkisinin incelendiği araştırmalara rastlanmadığı, daha çok ortaokul ve lise öğretim kademelerinde uygulandığının görülmesi bu çalışmanın diğer çalışmalara göre özgün olduğunu ortaya koymaktadır. Buradan hareketle, araştırmanın temel amacı, karikatüre dayalı öğrenme- öğretme modelinin okul öncesi öğrencilerin konuşma ve dinleme becerilerine etkisini belirlemektir. Araştırmada bu amaç doğrultusunda aşağıdaki sorulara yanıt aranmıştır.

1. Deney grubunun,

1.1 Ön test-son test, konuşma becerilerine ilişkin puanları arasında, anlamlı bir fark var mıdır?

1.2 Ön test-son test dinleme becerilerine ilişkin puanları arasında, anlamlı bir fark var midır? 
2. Kontrol grubunun,

2.1 Ön test-son test, konuşma becerilerine ilişkin puanları arasında, anlamlı bir fark var mıdır?

2.2 Ön test-son test dinleme becerilerine ilişkin puanları arasında, anlamlı bir fark var mıdır?

3. Deney ve kontrol grubunun,

3.1 Son test konuşma becerilerine ilişkin puanları arasında, anlamlı bir fark var mıdır? 3.2 Son test dinleme becerilerine ilişkin puanları arasında, anlamlı bir fark var mıdır?

4. Karikatüre dayalı öğrenme-öğretme modeli öğrencilerin

4.1 Konuşma becerisine katkısı nedir?

4.2 Dinleme becerisine katkısı nedir?

\section{YÖNTEM}

\section{Araştırma modeli:}

Araştırmada, baskın-daha az baskın karma yöntem deseni kullanılmıştır. Tashakkori ve Teddlie (1998) baskın-daha az baskın karma yöntem desenini, nitel veya nicel araştırma yöntemlerinden bir tanesini temele alıp, araştırmanın küçük bir boyutunda ise diğer araştırma deseninin kullanııması şeklinde tanımlamıştır.

\section{Çalışma Grubu:}

Araştırmada amaçsal örnekleme yöntemlerinden ölçüt örnekleme yöntemi kullanılmıştır. Araştırma kapsamında yer alan çocukların Bitlis'in Tatvan ilçesine bağlı anaokulu ve bu anaokullarında öğrenim gören 5 yaş grubu çocuklar olması ölçütleri aranmıştır. Çalışma grubunda yer alan deney grubu, araştırmacının eğitim-öğretim sürecini yürüttüğü grup, farklı bir anaokulu ise kontrol grubu olarak belirlenmiştir.

Deney grubunda yer alan etkinliklerde karikatürler belirlenirken günümüzün büyük sorunlarından olan "çevre kirliliği" ve "geri dönüşüm" ile ilgili konulara yer verilmiştir. Bu konular deney ve kontrol grubunda uygulanırken deney grubu öğrencilerine karikatüre dayalı öğrenmeöğretme modeli ile ilgili uygulamalar yapılmıştır. Kontrol grubuna ise mevcut eğitim programı doğrultusunda çalışmalar uygulanmıştır.

\section{Veri Toplama Araçları:}

Araştırmada karikatüre dayalı öğrenme öğretme modeline yönelik etkinlikler yapılırken , "Anlam bakımından karikatürlerden" "Mizah ve açıklayıcı-aydınlatıcı karikatürler ve bu doğrultuda Araştırmacılar tarafından geliştirilen yarı yapılandırıımış görüşme formu, konuşma ve dinleme becerilerini belirlemek amacıyla gözlem formu kullanılmıştır. Yarı yapılandırıımış görüşme formunda yer alan sorular için uzman görüşüne başvurulmuştur (Karikatür alanında çalışmaları bulunan iki, ölçme ve değerlendirme bir, eğitim programları ve öğretim anabilim dalındaki iki, okul öncesi öğretmeni 6, Türkçe öğretmeni iki). Uzmanlardan gelen görüşler doğrultusunda gerekli düzeltmeler yapılmıştır. Deney grubu öğrencilerine yönelik hazırlanan görüşme formunda yer alan sorular için her öğrenciye 10-15 dakika süre ayrılmıştır. Görüşmeler sınıf içerisinde yapılmıştır.

Araştırmada karikatüre dayalı öğrenme-öğretme modelinde kullanılan karikatürlerin öğrencilerin konuşma ve dinleme becerilerine katkılarını belirlemek amacıyla Araştırmacılar 
(2017) tarafından geliştirilen gözlem formu hazırlanmıştır. "Karikatüre dayalı öğrenme -öğretme modeli gözlem formu"nda bulunan sorular için "Çok kötü (1), kötü (2), orta (3), iyi (4), çok iyi (5) şeklinde beşli derecelendirme kullanılmıştır. Bunun yanı sıra araştırmada çeşitli karikatür örnekleri ve etkinliklerinden doküman incelemesi yoluyla alıntılar yapılmıştır.

Araştırmada deney grubu öğrencilerine Araştırmacılar tarafından hazırlanan karikatüre dayalı öğrenme- öğretme model uygulamaları; kontrol grubuna ise mevcut eğitim programı doğrultusundaki etkinlikler yapılmıştır. Yapılan etkinlikler altı haftada tamamlanmıştır.

\section{Verilerin Analizi:}

Araştırmanın çalışma grubuna yarı yapılandırılmış görüşme formu ve gözlem formu uygulanmıştır. Gözlem formu ve görüşme formu Yunus Emre Anaokulu'nda bulunan deney grubuna uygulanırken; gözlem formu Faki Teyran anaokulunda bulunan kontrol grubuna uygulanmıştır. Sınıf içerisinde öğrenci uygulamalarını gözlemlemek amacıyla video kayıt aracı kullanılmış ve araştırmacılar tarafından gözlem formunda yer alan becerilerin öğrenciler tarafından gerçekleştirilip gerçekleştirilmediğine bakılmıştır. Daha sonra bu videolar farklı okullarda görev yapan iki anaokulu öğretmenine gösterilmiş ve öğretmenlerin de gözlem formunda yer alan becerilerin öğrenciler tarafından yapılıp yapılmadığına ilişkin görüşlerine başvurulmuştur. Son olarak araştırmacılar ve öğretmenler tarafından doldurulan gözlem formunun puanları arasındaki puanlayıcı güvenirliğine bakılmış, bu değer 0.91 olarak bulunmuştur.

Verilerin analizinde konuşma ve dinleme becerilerine ilișkin hazırlanan gözlem formunda yer alan maddelerin normal dağılım gösterip göstermeme durumu için Shapiro-Wilks değerine bakılmıştır. Büyüköztürk'e (2014: 42) göre normal dağılım incelenirken grup sayısı 50' den küçükse Shapiro-Wilks, 50'den büyükse Kolmogorov-Simirnov testleri kullanılmaktadır. Normallik testleri doğrultusunda gözlem formundaki maddelerin normal dağılım göstermediği görülmüştür. Konuşma ve dinleme becerileri ile ilgili hazırlanan gözlem formunda deney ve kontrol grubundaki öğrencilerin puanlarını karşılaştırmak için Mann Whitney U-Testi, grupların kendi içindeki ön test - son test puanlarını karşılaştırmak için ise Wilcoxon İşaretli Sıralar Testi uygulanmıştır.

Yarı yapılandırılmış görüşme formunda ise elde edilen veriler için betimsel ve içerik analizi yöntemi kullanılmıştır. İçerik analizi yapılırken öncelikle öğrenci cevapları detaylı bir şekilde betimlenerek her bir soru için kodlar belirlenmiştir. Kodlar belirlenirken literatür taranmış, konuyla ilgili önceden geliştirilmiş kategoriler olup olmadığı incelenmiştir. Araştırmaya uygun kodlar belirlendikten sonra öğrenci cevapları sınıflandırılarak kaynak ve kodlama yoğunlukları tespit edilmiştir. Araştırmada nitel veri toplama ve analiz sürecinde iç ve dış geçerliği sağlamak amacıyla "inandırıcılık" ve "aktarılabilirlik" stratejileri kullanılmıştır. Öğrencilerle yapılan görüşmeler sonucunda elde edilen veriler öğrenci etkinlik ürünleriyle desteklenerek inandırıcılık sağlanmaya çalışılmıştır. Aktarılabilirlik konusunda öğrenci görüşleri herhangi bir yorum yapılmadan doğrudan aktarılmaya çalışı Imıştır. Doğrudan aktarım yapılırken öğrenciler için çeşitli kodlar kullanılmıştır. (örn. $\ddot{O}_{1}, \ddot{O}_{2} \ldots .$. ). Ayrıca nitel verilerin güvenilirliği için elde edilen veriler sayısallaştırılmış, frekans ve yüzde hesaplanmıştır.

Veriler 0,05 anlamlılık düzeyine göre test edilmiştir.

\section{BULGULAR}

\section{Deney grubunun ön test-son test konuşma becerilerine ilişkin puanlarına ait bulgular}

Deney grubunun ön test-son test konuşma becerilerine ilişkin puanlarına ait bulgular Tablo 1 'de verilmiştir. 


\section{Tablo 1:}

Deney grubunun, konuşma becerilerinin ön test- son test puanlarına ilişkin Wilcoxon Iş̧aretli Siralar Testi sonuçları

\begin{tabular}{lccccc}
\hline Son Test - Ön Test & \multicolumn{3}{c}{ Sıra } & Sıra \\
& N & Ortalaması & Toplamı & z & p \\
\hline Negatif Sıralar & 1 & 5 & 5 & & \\
\hline Pozitif Sıralar & 19 & 10,79 & 205 & -3.737 & $0.00^{\star}$ \\
\hline Fark olmayan & 1 & & & \\
\hline TOPLAM & 21 & & \\
\hline
\end{tabular}

Tablo 1'de görüldüğü üzere, öğrencilerin ön test-sontest konuşma becerilerine ilişkin puanları arasında anlamlı farklılığın son test lehine olduğu görülmektedir [ $z=-3.737, p \leq 0.05]$. Buradan hareketle, karikatüre dayalı öğrenme- öğretme modelinin deney grubu öğrencilerin konuşma becerilerine katkı sağladığı söylenebilir.

\section{Deney grubunun ön test-son test dinleme becerilerine ilişkin puanlarına ait bulgular}

Deney grubunun ön test-son test dinleme becerilerine ilişkin puanlarına ait bulgular Tablo 2 'de verilmiştir.

\section{Tablo 2:}

Deney Grubunun, dinleme becerilerinin ön test- son test puanlarına ilişkin Wilcoxon Işaretli Stralar Testi sonuçları

\begin{tabular}{llllll}
\hline Son Test - Ön Test & \multicolumn{2}{c}{ Sıra } & Sıra & & \\
& $\mathbf{N}$ & Ortalaması & Toplamı & $\mathbf{z}$ & $\mathbf{p}$ \\
\hline Negatif Sıralar & 3 & 3,33 & 10 & & \\
\hline Pozitif Sıralar & 18 & 12,28 & 221 & $-3,669$ & $0.00^{*}$ \\
\hline Fark olmayan & 0 & & & \\
\hline TOPLAM & 21 & & & \\
\hline
\end{tabular}

Tablo 2'de görüldüğü üzere, öğrencilerin ön test-sontest dinleme becerilerine ilişkin puanları arasında anlamlı farklılığın son test lehine olduğu görülmektedir [ $z=-3.669, p \leq 0.05]$. Buradan hareketle, karikatüre dayalı öğrenme- öğretme modelinin deney grubu öğrencilerin dinleme becerilerine katkı sağladığı söylenebilir.

\section{Kontrol grubunun ön test-son test konuşma becerilerine ilişkin puanlarına ait bulgular}

Kontrol grubunun ön test-son test konuşma becerilerine ilişkin puanlarına ait bulgular Tablo 3'de verilmiştir. 
Tablo 3:

Kontrol grubunun, konuşma becerilerinin ön test- son test puanlarına ilişkin Wilcoxon Iş̧aretli Sıralar Testi sonuçları

\begin{tabular}{|c|c|c|c|c|c|}
\hline \multirow[t]{2}{*}{ Son Test - Ön Test } & & Sira & Sira & & \\
\hline & $\mathbf{N}$ & Ortalaması & Toplamı & $\mathbf{z}$ & $\mathbf{p}$ \\
\hline Negatif Sıralar & 5 & 12,30 & 61,50 & & \\
\hline Pozitif Sıralar & 15 & 9,90 & 148,50 & -1.626 & 0.10 \\
\hline Fark olmayan & 4 & & & & \\
\hline TOPLAM & 24 & & & & \\
\hline
\end{tabular}

Tablo 3'de görüldüğü üzere, öğrencilerin ön test-sontest konuşma becerilerine ilişkin puanları arasında anlamlı farklıık görülmemiştir $[z=-1,626, p>0.05]$. Buradan hareketle, mevcut eğitim programı doğrultusunda yapılan etkinliklerin öğrencilerin konuşma becerilerine katkı sağlamadığı söylenebilir.

\section{Kontrol grubunun ön test-son test dinleme becerilerine ilişkin puanlarına ait bulgular}

Kontrol grubunun ön test-son test dinleme becerilerine ilişkin puanlarına ait bulgular Tablo 4'de verilmiştir.

\section{Tablo 4:}

Kontrol grubunun, dinleme becerilerinin ön test- son test puanlarına ilişkin Wilcoxon Işsaretli Sıralar Testi sonuçları

\begin{tabular}{lccccc}
\hline Son Test - Ön Test & & Sıra & Sıra \\
& N & Ortalaması & Toplamı & z & $\mathbf{p}$ \\
\hline Negatif Sıralar & 4 & 14,88 & 59 & & \\
\hline Pozitif Sıralar & 14 & 7,96 & 111,50 & $-1,133$ & 0.25 \\
\hline Fark olmayan & 6 & & & \\
\hline TOPLAM & 24 & & \\
\hline
\end{tabular}

Tablo 4'de görüldüğg̈ü üzere, öğrencilerin ön test-sontest dinleme becerilerine ilişkin puanları arasında anlamlı farklılık görülmemiștir $[z=-1,133, p>0.05]$. Buradan hareketle, mevcut eğitim programı doğrultusunda yapılan etkinliklerin öğrencilerin dinleme becerilerine katkı sağlamadığı söylenebilir.

\section{Deney ve kontrol grubunun, son test konuşma becerilerine ilişkin puanlarına ait bulgular}

Deney ve kontrol grubunun, son test konuşma becerilerine ilişkin puanlarına ait bulgular Tablo 5'de verilmiştir. 


\section{Tablo 5:}

Deney ve kontrol grubunun son test konuşma becerilerine ilişkin puanlarının Mann Whitney UTesti sonuçları

\begin{tabular}{cccccc}
\hline Gruplar & N & $\begin{array}{c}\text { Sıra } \\
\text { Ortalaması }\end{array}$ & $\begin{array}{c}\text { Toplamı } \\
\text { Topla }\end{array}$ & U & p \\
\hline Deney & 21 & 29,40 & 617,50 & 223 & $0.00^{*}$ \\
Kontrol & 24 & 17,40 & 417,50 & & \\
\hline
\end{tabular}

Tablo 5'de görüldüğü üzere, öğrencilerin sontest konuşma becerilerine ilişkin puanları arasında anlamlı farklılığın olduğu görülmektedir $[U=223, p \leq 0.05]$. Sıra ortalamaları incelendiğinde deney grubundaki öğrencilerin konuşma becerilerine ilişkin puanların $(29,40)$, kontrol grubu öğrencilerden $(17,40)$ yüksek olduğu görülmektedir. Buradan hareketle, karikatüre dayalı öğrenme- öğretme modelinin deney grubundaki öğrencilerin konuşma becerilerine katkı sağladığı söylenebilir.

\section{Deney ve kontrol grubunun, son test dinleme becerilerine ilişkin puanlarına ait bulgular}

Deney ve kontrol grubunun son test, dinleme becerilerine ilişkin puanlarına ait bulgular Tablo 6'da verilmiştir.

\section{Tablo 6:}

Deney ve kontrol grubunun son test, dinleme becerilerine ilişkin puanlarının Mann Whitney U Testi sonuçları

\begin{tabular}{llcccc}
\hline Gruplar & N & $\begin{array}{c}\text { Sira } \\
\text { Ortalaması }\end{array}$ & $\begin{array}{c}\text { Sira } \\
\text { Toplamı }\end{array}$ & U & p \\
\hline & & & & & \\
Deney & 21 & 26,38 & 554 & 181 & $0.00^{*}$ \\
Kontrol & 24 & 20,04 & 481 & & \\
\hline
\end{tabular}

Tablo 6'da görüldüğü üzere, öğrencilerin sontest dinleme becerilerine ilişkin puanları arasında anlamlı farklılığın olduğu görülmektedir $[U=181, p \leq 0.05]$.Sıra ortalamaları incelendiğinde deney grubundaki öğrencilerin dinleme becerilerine ilişkin puanların $(26,38)$, kontrol grubu öğrencilerden $(20,04)$ yüksek olduğu görülmektedir. Buradan hareketle, karikatüre dayalı öğrenme- öğretme modelinin deney grubundaki öğrencilerin dinleme becerilerine katkı sağladığı söylenebilir.

\section{Karikatüre dayalı öğrenme-öğretme modelinin öğrencilerin, konuşma becerisine katkısına ilişkin bulgular}

Karikatüre dayalı öğrenme-öğretme modelinin öğrencilerin, konuşma becerisine katkısına ilişkin bulgular Tablo 7'de verilmiştir. 
Tablo 7:

Karikatüre dayalı ögrenme-ögrretme modelinin ögrrencilerin, konuşma ve dinleme becerisine katkısına ilişkin betimsel analiz sonuçları

\begin{tabular}{|c|c|c|c|c|c|}
\hline & \multirow[t]{2}{*}{ Kategori } & \multicolumn{2}{|c|}{ Kaynak } & \multicolumn{2}{|c|}{$\begin{array}{l}\text { Kodlama } \\
\text { Yoğunluğu }\end{array}$} \\
\hline & & $\mathbf{f}$ & $\%$ & $f$ & $\%$ \\
\hline \multirow[t]{4}{*}{ Karikatür nedir? } & Eğlence & 10 & 47.61 & 10 & 45.45 \\
\hline & Düşünme & 6 & 28.57 & 7 & 31.81 \\
\hline & Abartılı çizgiler & 5 & 23.80 & 5 & 22.72 \\
\hline & TOPLAM & 21 & 100 & 22 & 100 \\
\hline \multirow[t]{5}{*}{ Hangi karikatürleri sevdin? } & Komik karikatürler & 10 & 47.61 & 12 & 41.37 \\
\hline & Renkli karikatürler & 5 & 23.80 & 7 & 24.13 \\
\hline & Yazılı karikatürler & 3 & 14.28 & 5 & 17.24 \\
\hline & Yazısız karikatürler & 3 & 14.28 & 5 & 17.24 \\
\hline & TOPLAM & 21 & 100 & 29 & 100 \\
\hline \multirow{3}{*}{$\begin{array}{c}\text { En çok hangi karikatürler } \\
\text { üzerinde konuştunuz? }\end{array}$} & Eğlenceli karikatürler & 12 & 57.14 & 13 & 56.02 \\
\hline & Bilgi içerikli karikatürler & 9 & 42.85 & 10 & 43.47 \\
\hline & TOPLAM & 21 & 100 & 23 & 100 \\
\hline \multirow{4}{*}{$\begin{array}{c}\text { Arkadaşlarının ve öğretmenin } \\
\text { gösterdiği karikatürleri } \\
\text { dinlerken neye dikkat ettin? }\end{array}$} & Seçici dinleme & 10 & 47.61 & 11 & 42.30 \\
\hline & Eleştirel dinleme & 7 & 33.33 & 10 & 43.47 \\
\hline & Gönüllü dinleme & 4 & 19.04 & 5 & 21.73 \\
\hline & TOPLAM & 21 & 100 & 26 & 100 \\
\hline \multirow{4}{*}{$\begin{array}{c}\text { Dinlerken karikatürler ile ilgili } \\
\text { ne öğrendin? }\end{array}$} & Problem çözme & 9 & 42.85 & 10 & 45.45 \\
\hline & Sosyalleşme & 9 & 42.85 & 7 & 31.81 \\
\hline & Hoşgörü & 3 & 14.28 & 5 & 22.72 \\
\hline & TOPLAM & 21 & 100 & 22 & 100 \\
\hline
\end{tabular}

Tablo 7'de görüldüğü üzere, 21 öğrenci ile yapılan görüşmelerin betimsel analiz sonuçlarında karikatür "eğlence" düşünme" ve abartılı çizgiler" kategorisi altında toplanarak tanımlanmıştır. Eğlence kategorisinde [karikatürlerin çok komik çizimler olduğu $(f=4)$, zevk veren resimler içerdiği $(f=3)$, iletişim kurmaya yarayan araçlar olduğu $(f=3)]$ görülmüştür. Düşünme kategorisinde [düşünmeyi sağlayan resimler $(f=4)$, merak duygusu uyandıran komik yapılar $(f=3)$ ]; abartılı çizgiler kategorisinde ise [çizimlerin bir biri ile uyumlu olmadığı resimler $(f=3)$, gerçek yaşamdan farklı nesneler $(f=2)$ ] olarak tanımlamaktadırlar.

Tablo 7'ye göre, öğrenciler komik, renkli, yazılı ve yazısız karikatürleri daha çok sevmektedirler. Komik karikatürler kategorisinde [eğlenceli $(f=4)$, zevk veren $(f=3)$, üzerinde çok konuşulan $(f=3)$, çok güldüren $(f=2)]$ karikatürleri sevdikleri görülmüştür. Renkli karikatürlerden [pastel boyalı olanlar $(f=3)$, kuru boyalarla boyananlar $(f=2)$, farklı boyaların kullanıldığı karikatürleri $(f=2)$ ] sevdikleri söylenebilir. Yazılı karikatürlerden ise (üzerinde açıklamaların olduğu karikatürleri $(f=3)$, resimlerdeki kişilerin ne konuştuğunu açıklayan karikatürleri $(f=2)]$; yazısız karikatürlerden ise (herhangi bir konuşmanın olmadığı $(f=3)$, sadece resimlerin olduğu $(\mathrm{f}=2)$ ] karikatürleri sevmektedirler.

Tablo 7'ye göre, eğlenceli karikatürler üzerinden (onları güldüren $(f=5)$, onların dikkatini çeken $(f=4)$, aktif konuşma sürecine katan $(f=4)$ ]; bilgi içerikli karikatürlerden [bilmedikleri konulardan açıklama yapan $(f=4)$, eksik bilgilerini tamamlayan $(f=3)$, düşünmeyi sağlayan $(f=3)$ ] konuştukları görülmektedir.

Tablo 7'de görüldüğü üzere, öğrenciler karikatüre dayalı öğrenme-öğretme modeli ile yapılan etkinliklerde seçici dinlerken [her açıklamayı dinlemediği $(f=5)$, onların dikkatini çeken 
açıklamaları dinledikleri $(f=3)$, önemli ve önemsiz konuları ayırt ettikleri $(f=3)]$; eleştirel dinlerken (olayların olumlu-olumsuz yönlerini dikkat ettiği $(f=4)$, farklı fikirler ortaya koyduğu $(f=3)$, günlük yaşamda karşılaşııp karşılaşılmadığı $(f=3)$ ]; gönüllü dinlerken [sevdiği karikatürlerin açıklamalarını dinlediği $(f=3)$, isteyerek katılım gösterdiği $(f=2)]$ söylenebilir.

Tablo 7'de görüldüğü üzere, karikatürler dayalı öğrenme-öğretme modeli öğrencilerde problem çözmeyi [başkalarının problem çözme süreçlerini dinleyerek anlama $(f=4)$, dinlediklerini açıklama ( $f=2)$, yorum yapma $(f=2)$, kendi çözümü ile dinledikleri arasında farkı görme $(f=2)]$; sosyalleşmeyi [iletişim $(f=3)$, işbirliği $(f=2)$, dinlediklerini paylaşma $(f=2)$ ]; hoşgörülü olmayı [başkalarını dinlerken saygılı olmayı $(f=3)$, dinlediklerini empati kurarak açıklamayı $(f=2)$ ] öğrendikleri görülmüştür.

Buradan hareketle, çocuklar karikatürü komik çizimler (örn.1-2-3-4), zihni aktif tutan çizimler (örn.5-6-7-8), çizimler arasında bütünlüğün olmadığı resimler (örn.9-10-11) olarak tanımlamaktadırlar. Öğrenciler daha çok eğlenceli karikatürleri (örn.12-13-14-15), pastel olarak boyanan karikatürler (örn.16-17-18) sevdikleri görülmüştür. Ayrıca, öğrenciler karikatürlerde çeşitli konuşmaların yer aldığı (örn.19-20-21) ve herhangi bir açıklamanın bulunmadığı sadece resimlerin/çizimlerin olduğu (örn.22-23-24) karikatürleri sevmekte, onları eğlendiren (örn.25-2627-28-29), onlara mesajlar veren (örn.30-31-32-33)karikatürler üzerinde konuşmaktadır.

Öğrencilerle yapılan görüşmelerde, öğrencilerin her konuyu dinlemedikleri (örn.34-35-3637), olayların avantaj ve dezavantajlarını dikkate aldıkları (örn.38-39-40-41), sevdiği karikatürleri dinledikleri (örn.42-43-44) söylenebilir. Son olarak öğrenciler başka bireylerin problemlerin çözümü ile ilgili açıklamaları dikkatlice dinledikleri (örn.45-46-47-48), dinledikleri olayları, bilgileri ve açıklamaları anlamak için iletişim kurdukları (örn.49-50-51) ve başkalarının sözlerini kesmeden dinledikleri (örn.52-53-54) söylenebilir.

[1] "öğretmenim çok komik resimler vardı" (Ö

[2] "karikatür çok hoşuma gitti bence komik şeyler" $\left(\ddot{O}_{15}\right)$

[3]"komik şeyler......̧̧ok komikti" $\left(\mathrm{O}_{1}\right)$

[4]"bence bize komik gelen her şey" $\left(\ddot{O}_{11}\right)$

[5] "öğretmenim siz gösterince diğer karikatürü merak ettim" $\left(\mathrm{O}_{1}\right)$

[6]"siz soru sorunca üzerinde düşünüyordum" $\left(\ddot{O}_{1}\right)$

[7]"arkadaşlarım konuşunca düşünmemi sağladı" $\left(\mathrm{O}_{1}\right)$

[8]"karikatürlerde ne anlatılıyor, konuşuluyor düşünüyordum" $\left(\ddot{O}_{3}\right)$

[9]"yaa....karikatür böyle resimler uyumlu olmaması bence" $\left(\ddot{O}_{6}\right)$

[10]"karikatür böyle tam olarak uyumlu olmayan şeyler" (Ö $\left.{ }_{18}\right)$

[11]"çok şeyler var her şey karikatürde var" $\left(\mathrm{O}_{21}\right)$

[12]"ayy çok komikti öğretmenim..." $\left(\mathrm{O}_{20}\right)$

[13]"çok eğlendim" (Ö̊)

[14]"bir tane karikatür çok güldüm öğretmenim" $\left(\mathrm{O}_{10}\right)$

[15] "arkadaşımla çok güldük çok eğlendim keşke hep olsa öğretmenim" (Ö)

[16]"hani öğretmenim böyle canlı renkler vardı onları çok sevdim" (Ö $\left.{ }_{14}\right)$

[17]"parlak renkler hoşuma gitti" (Ö $\left.{ }_{17}\right)$

[18]"ilk gösterdiğiniz karikatürler çooook sevdim" (Ö)

[19]"yanında bize okuduğunuz karikatürler çok güzeldi" (Ög)

[20]"resme bakınca bazen bir şey anlamıyordum ama siz okuyunca anlıyordum" (Ö $\left.{ }_{1}\right)$

[21]"en güzel bize okuduğunuz karikatürler" (Ö $\left.{ }_{3}\right)$

[22]"öğretmenim yanında yazı olunca dikkatim dağıııor" $\left(\ddot{O}_{6}\right)$

[23]"siz okuyunca resme bakamıyordum en güzeli yazı olmasın" $\left(\ddot{O}_{11}\right)$ 


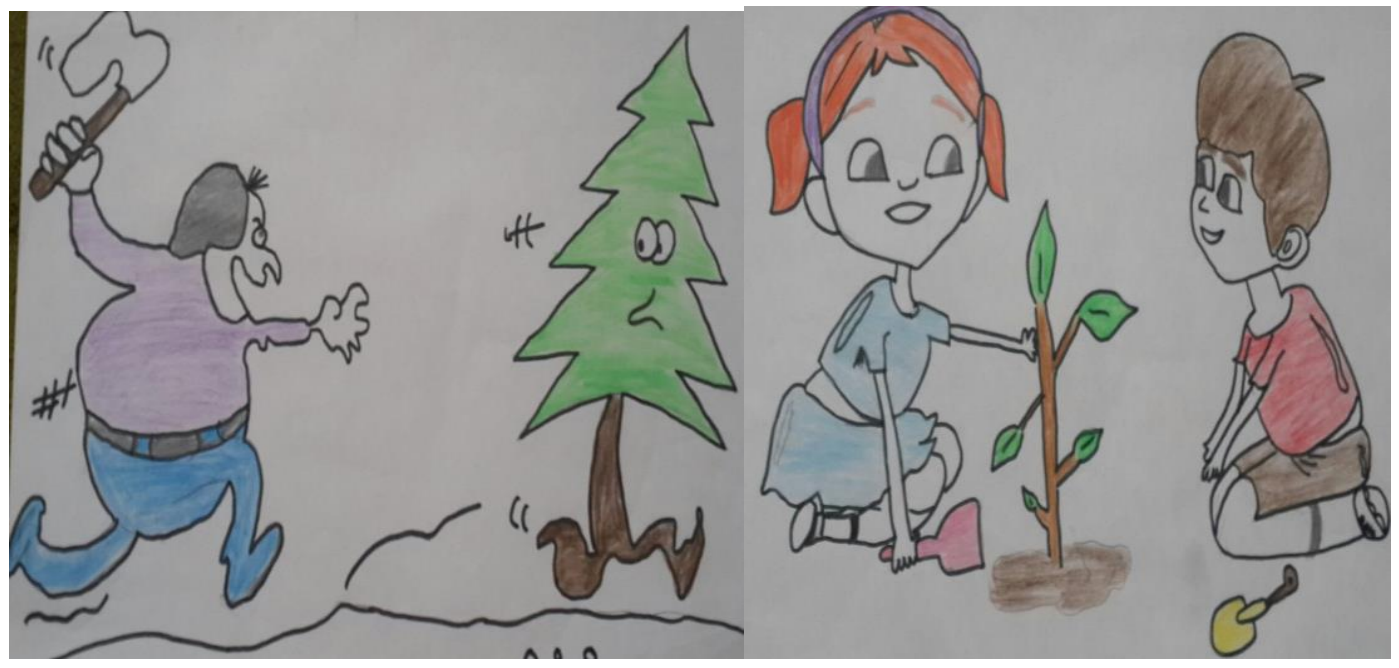

Resim 1: Yazısız karikatürler

[24]"sadece resim olsun öğretmenim" ( $\left.\ddot{O}_{13}\right)$

[25]" öğretmenim ben komik olanlar üzerinde konuştum" ( $\left.\ddot{O}_{19}\right)$

[26]"öğretmenim arkadaşımla bizi güldürenler hakkında çok konuştuk" $\left(\mathrm{O}_{3}\right)$

[27]"arkadaşım hep komik olanları konuştu" (Ö)

[28]"öğretmenim hani ilk gösterdikleriniz var ya onları çok konuştuk" (Ö)

[29]"bana kalsa çok konuşacaktım öğretmenim....çok komik karikatürler ile ilgili" (Ö $\left.{ }_{11}\right)$

[30]"aslında çok şey öğrendim" $\left(\ddot{O}_{20}\right)$

[31]"çevremiz ne kadar önemli öğretmenim onu öğrendim" (Ö $\left.{ }_{18}\right)$

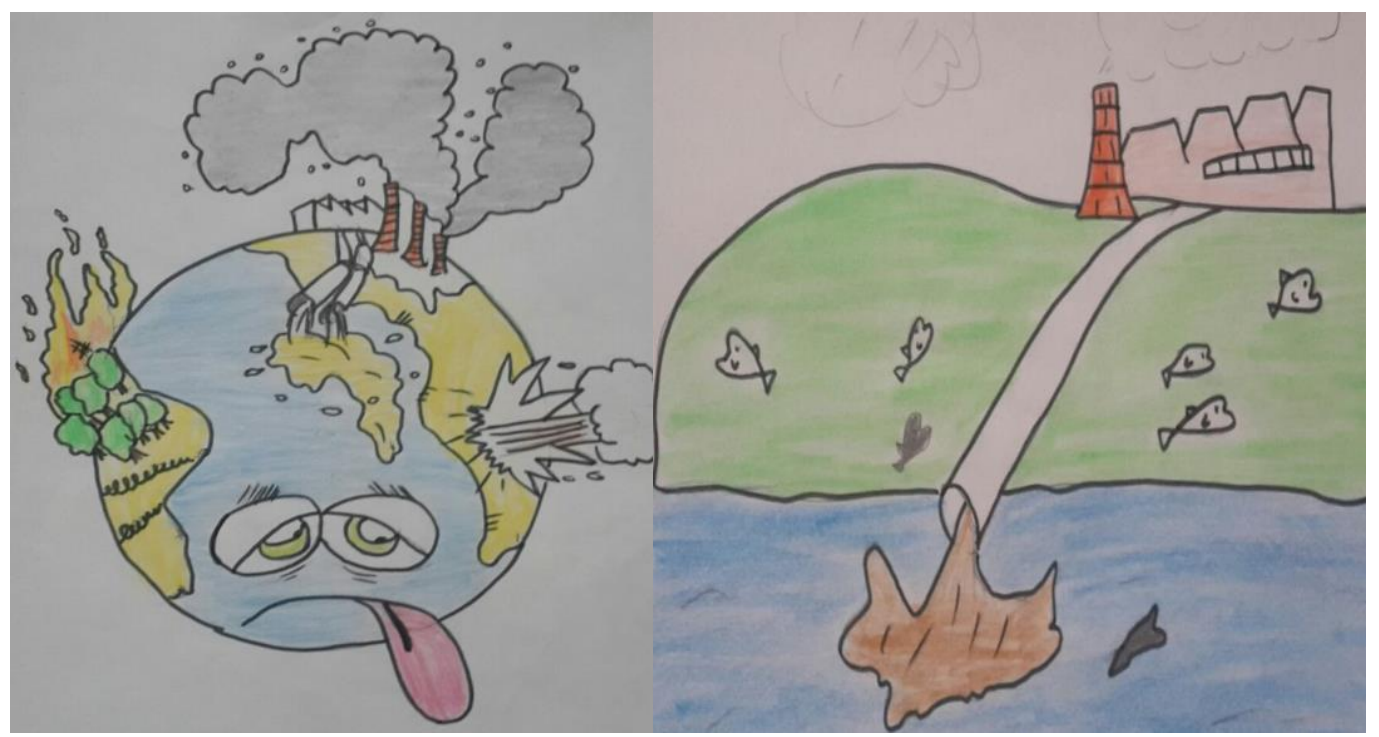

Resim 2: Renkli karikatürler

[32]"evimizi okulumuzu temiz tutmalıyı" $\left(\mathrm{Ö}_{1}\right)$

[33]"ben bir şey yapıyordum öğretmenim artık o resimlere baktım yapmayacağım" (Ö $\left.{ }_{1}\right)$

[34]"öğretmenim her şeyi dinlemek istemedim" $\left(\ddot{O}_{1}\right)$

[35]"bazen arkadaşım konuşunca onun söylediklerini dinlemedim" $\left(\mathrm{O}_{1}\right)$

[36]"yanımdaki arkadaşımın söylediklerini dinledim" (Ö̈)

[37]"her şeyi dinleyemeyiz ki öğretmenim" (Ö $\left.{ }_{1}\right)$

[38]"resimleri görünce bir şey aklıma takılınca dinledim sonra soru sordum" (Ö)

[39]"bir resim vardı ben oradaki anlatılanları sevmedim" (Ö $\left.{ }_{1}\right)$

[40]"çevremize dikkat etmeliyiz resimde bize o söyleniyordu" $\left(\mathrm{O}_{1}\right)$ 
[41]"eğer öğretmenim resimlere dikkatli bakmazsak bir şey

konuşamayız dinleyemeyiz..."

[42]"çok istedim dinlemeyi ....̈̈yle yaptım...." $\left(\ddot{O}_{1}\right)$

[43]"keşke hep karikatür olsa......." $\left(\mathrm{O}_{1}\right)$

[44]"çok isteyerek dinledim çok hoşuma gitti" (Ö)

[45]"siz soru sorunca dikkatlice dinledim" (Ö)

[46]" arkadaşım karikatürle ilgili açıklama yapınca dinledim" (Ö)

[47]"hani bir olay vardı onu arkadaşım konuşunca dikkatimi çekti" $\left(\ddot{O}_{1}\right)$

[48]"siz resmi gösterince bir çocuk bir şey yapmıştı dinledim sizi sonra arkadaşıma söyledim" $\left(\ddot{O}_{1}\right)$

[49]"......anlamadığım yerleri arkadaşıma sordum ama ilk önce dinledim" (Ö 1 )

[50]"önce iyice dinledim sonra size soru sordum" $\left(\mathrm{Ö}_{1}\right)$

[51]"bence önce dinlemeliyiz başkalarını sonra konuşmalıyız" $\left(\ddot{O}_{1}\right)$

[52]"dinlerken başkalarının sözlerini kesmemeliyiz" $\left(\ddot{O}_{1}\right)$

[53]"sizi çok usluca dinledim" (Ö)

[54]"arkadaşım konuşunca onu dinlemeliyiz" (Ö

\section{TARTIŞMA, SONUÇ VE ÖNERILER}

Karikatüre dayalı öğrenme-öğretme modelinin deney grubunun ön test-son test konuşma becerilerine ilişkin puanlarında son test lehine bir farklılaşma görülmüştür. Deney grubu öğrencilerinin karikatüre dayalı öğrenme-öğretme modeli uygulamaları ile kısa cümleler kurmadığı, anlamadıkları resim ve nesneler hakkında soru sordukları, düşüncelerini farklı şekillerde ifade ettikleri vs. sonucuna ulaşılmıştır. Başka bir deyişle, karikatüre dayalı öğrenmeöğretme modeli öğrencilerde olaylara çok yönlü bakmayı, farklı düşünceler ortaya koymayı sağlamaktadır. Balım, İnel ve Evrekli'ye (2008) göre, karikatürlerle bireyler alternatif düşünceler geliştirmekte, bu düşünceleri sorgulamakta, elde ettikleri yeni düşünceleri farklı alanlara transfer etmektedir.

Karikatüre dayalı öğrenme-öğretme modelinin deney grubunun ön test-son test dinleme becerilerine ilişkin puanlarında son test lehine bir farklılık görülmüştür. Karikatüre dayalı öğrenme-öğretme modeli etkinlikleri ile öğrencilerin arkadaşlarının etkinliklerini ve açıklamalarını dikkatlice dinledikleri, anlamadıkları ve merak ettikleri konular hakkında sorular sordukları sonucuna ulaşılmıştır. Karikatüre dayalı öğrenme ile öğrenciler zihinlerinde oluşan belirsizlikleri soru sorarak gidermekte ve çevresinde gelen uyarıcıları bilişsel yapısında seçmektedir (Balım, İnel ve Evrekli, 2008:199).

Kontrol grubunun ön test-son test konuşma ve dinleme becerilerine ilişkin puanlarında anlamlı farklılık görülmemiştir.

Deney ve kontrol grubunun, son test konuşma becerilerine ilişkin puanlarında deney grubunun son test lehine farklılaşma görülmüştür. Karikatüre dayalı öğrenme-öğretme modeli ile yapılan etkinliklerle deney grubu öğrencilerinin anlamadıkları ile ilgili sorular sorup, çeşitli tahminlerde bulunabildikleri, gördükleri ile ilgili sorular sorabildikleri ve bunları yaparken nedensonuç ilişkisini daha anladıkları sonucuna ulaşılmışır. Kontrol grubunda ise herhangi bir değişmenin meydana gelmediği sonucuna ulaşılmıştır. Çakır ve Aydoğdu (2016) öğretmenler öğrencilerin derse ilgilerini çekmek amacıyla ve çocukların konular hakkında tahmin yürütebilmelerini ve neden sonuç ilişkisi kurup konular hakkında yorum yapabilmelerini sağlamak için derslerde karikatür kullanımına önem verilmesi gerektiğini açıklamışlardır. Aynı şekilde Ersoy ve Türkkan'ın (2010) da değindiği gibi karikatür çizimi ile öğrencilerin sosyal ve çevresel bir durum üzerinde tahmin yürütebilecekleri, konu ile ilgili karikatür çizebilecekleri ve çizdikleri bu karikatürlere duygu ve düşüncelerini aktarabildikleri öğrenme ortamlarında etkili öğretimin gerçekleşebileceği açıklanmıştır. 
Deney ve kontrol grubunun, son test dinleme becerilerine ilişkin puanlarında deney grubunun son test lehine farklılaşma görülmüştür. Karikatüre dayalı öğrenme-öğretme modeli ile yapılan etkinliklerle deney grubu öğrencilerinin duyduklarına yönelik sorulan sorulara kendi yaşamından da örnekler verebildiği, duyduklarını diğer arkadaşlarıyla paylaşabildiği sonucuna ulaşılmıştır. Kontrol grubunda ise herhangi bir değişimin olmamıştır. Bu sonuç, diğer araştırmacılar Keogh, Naylor ve Wilson (1998), Stephenson ve Warwick (2002) ve Keogh ve Naylor (1999) tarafından belirtilen kavram karikatürlerinin sahip olması gereken özellikleri destekleyici yöndedir. Mesela, yaş grubuna uygun olarak kavram karikatürlerinde öğrencilerin kolaylıkla anlayabileceği kısa metinler kullanılmakta ve bu metinler diyalog halinde öğrencilere sunulmaktadır. Böylece sınırlı dil bilgisine sahip olan öğrenenler için de kavram karikatürleri ulaşılabilir olmaktadır. Kavram karikatürleri öğrencileri tartışmaya katılmaya davet etmektedir.

Öğrenenlerin bilim ve günlük yaşam arasında ilişki kurmasını sağlamak için, bilimsel düşüncelerin günlük yaşama uyarlanabilir olması gerekmektedir. Kavram karikatürleri, özellikle öğrencilerin birbirleriyle görüş alışverişi yapmalarına ve kavramlara ilişkin tartışmalarına yol açmaktadır. Bu nedenle, karakterler arasında tartışma oluşturmak için karikatür biçimini kullanan (Keogh ve Naylor, 1999) kavram karikatürleri öğrenciler arasında tartışmaların başlatılması için bir başlangıç noktası sağlamak amacıyla kullanılabilen yararlı araçlardır (İnel ve Balım, 2011). Buradan hareketle, karikatüre dayalı öğretimin çocukların kendilerine yakın hissettiği ve uygun gördüğü karikatürler hakkında konuşmaya ve dinlemeye daha fazla katılım gösterdikleri, karikatürle yapılan öğretimde çocukların dil becerilerinin de olumlu yönde geliştiği söylenebilir. Sidekli ve Aydın'a (2014) göre de eğitimde karikatürler yalnızca görsel bir araç olarak değil aynı zamanda mizahı da içinde barındıracak şekilde hazırlanmalıdır. Karikatür ile yapılan etkinliklerle ve uygulamalarla öğrenciye istenilen mesaj verilebilir. Yine Sidekli ve Aydın'a (2014) göre karikatür yoluyla öğrencilerin sözel iletişimi ve öğrenmelerini daha etkili bir seviyeye getirmek mümkün olabilir. Karikatür öğrencilerin dil ve düşünce ile ilgili birçok becerisini geliştirmeye yardımcı olmakta ve öğrencinin kendinde bulunan özelliklerini fark etmesine yardımcı olmaktadır.

Karikatüre dayalı öğrenme-öğretme modelinde yapılan uygulamalarla öğrencilerin karikatürü eğlenceli olarak açıkladıkları, onların düşünmelerini sağladıkları, birbiri ile uyumlu olmayan resimlerden oluştuğu şeklinde tanımladıkları sonucuna ulaşılmıştır. Bu bulgu kavramsal karikatürlerin bir tartışma yaratmak, kavramsal tartışmaya davet etmek ve derse katıımı sağlamak olan özelliğini destekleyecek niteliktedir.

Öğrencilerin onları eğlendiren pastel boyalı olan yanında açıklamaların yer aldığı ve bazı resimlerde açıklamaların olmadığı karikatürleri daha çok sevdikleri görülmüştür. Topçubaşı ve Polat'ın (2014) da değindiği gibi karikatüre dayalı öğretimde çocuklar karikatürde bulunan karakter ile durumu daha iyi kavrayabilir ve bu doğrultuda da kendi düşüncelerini de daha iyi ifade edebilir. Öğrenciler mizahi yönü ve bilgi içerikli olan karikatürler üzerinde daha fazla konuşarak katılım gösterdikleri sonucuna ulaşılmıştır. Yani öğrencilerin karikatürlerle ilgili her açıklamayı dinlemedikleri, karikatürlerde verilen mesajların olumlu ve olumsuz yönlerini dikkate aldıkları, sorulan sorulara ve etkinliklere istekli olarak katılım gösterdikleri görülmüştür. Öğrencilerin ilgilerini çeken karikatürlerde sınıf tartışmalarına daha fazla katııım gösterdikleri bu konuda yapılan diğer çalışmalarda da görülmüştür (Ersoy ve Türkkan, 2010).

Öğrencilerin karikatüre dayalı öğrenme- öğretme modeliyle farklı düşünceleri dinledikleri, karikatürde karşılaşılan problemleri çözebilme becerisine sahip oldukları ve arkadaşlarını dinlerken hoşgörülü oldukları görülmüştür. Karikatüre dayalı öğrenme ile düşünceler görselleştirilebilir, öğrenciler belleğe işlenen ve yapılandırdıkları bilgileri karikatürde verilen problem durumunu çözebilmek için bu dikkat ve ilgilerinden faydalanabilirler (Kuşakçı Ekim, 2007).

Karikatüre dayalı olarak yapılan araştırmalarda ortak nokta karikatürün derse eklenmesinin öğrenmeye katkı sağladığıdır. Karikatürün eğitim sürecinde önemli olduğunu gösteren, bir 
öğrenme aracı olarak kullanılmasını destekleyen birçok araştırma mevcuttur (Özalp, 2006; Özer, 2007; İnel ve Balım, 2011; Köseoğlu, 2009; Şengül, 2011).Özalp (2006) fen bilgisi dersinde karikatürlerle yapılan öğretimin, geleneksel metotlara göre daha başarılı olduğunu göstermiştir. Kılıç (2008) çalışmasında karikatürleri ile yapılan öğretimin öğrencilerin başarılarını, biyolojiye /yönelik tutumlarını ve motivasyonlarını düz anlatım metoduna göre anlamlı ve pozitif oranda arttırdığı sonucuna ulaşmıştır. Köseoğlu (2009), ilköğretim öğrencileri üzerine yaptığı araştırmada, sosyal bilgiler dersinde karikatür kullanımının öğrencilerin eleştirel düşünme becerisini geliştirdiğini ortaya koymuştur. Özşahin (2009), çalışmasında karikatür kullanımının öğrencilerin coğrafya derslerine olan ilgisini arttırdığını belirlemiştir. Aksoy, Karatekin, Kuş ve Sönmez (2010) yaptığı çalışmada, Sosyal Bilgiler dersinde karikatür kullanımının öğrencilerin akademik başarılarını arttırdığı sonucuna ulaşılmıştır. Yapılan araştırmalarda karikatürlerin daha çok fen bilimleri ve sosyal bilgiler derslerinde kullanıldığı ve çalışmalarda olumlu etkinin olduğu görülmektedir.

\section{Öneriler}

> Karikatüre dayalı öğrenme- öğretme modeli okul öncesi öğrenciler üzerinde yürütülmüştür. Bu model farklı sınıf düzeyleri üzerinde yürütülebilir.

> Karikatüre dayalı öğrenme- öğretme modelinin öğrencilerde hangi becerileri geliştirdiği araştırılabilir.

> Karikatüre dayalı öğrenme- öğretme modelinin öğrencilerde diğer dil becerileri(okuma, yazma, dinleme ve konuşma) üzerindeki etkisi araştırılabilir.

\section{KAYNAKLAR}

Aksoy, B., Karatekin, K., Kuş, Z. ve Sönmez, Ö. F. (2010, Mayıs). Sosyal bilgiler öğretiminde karikatür kullanımının öğrencilerin akademik başarısına etkisi. IX. Sını Öğretmenliği Sempozyumu, 20-22 Mayıs 2010, Elazığ.

Balım, A. G., İnel, D. ve Evrekli, E. (2008). Fen öğretiminde kavram karikatürü kullanımının öğrencilerin akademik başarılarına ve sorgulayıcı öğrenme becerileri algılarına etkisi. ilköğretim Online, 7(1), 188202, 2008. [Online].

Bing K. W., ve Tam, C.H. (2003). A fresh look at cartoons as a media of instruction in teaching mathematics and science in malaysian schools: A hands-on experience. ELTC, Malaysia: Conference: Managing Curricular Change.

Büyüköztürk, Ş. (2014). Sosyal Bilimler İçin Veri Analizi El Kitabı, 20. Baskı, Ankara: Pegem Akademi.

Coll, R. K. (2005). The role of models/and analogies in science education: Implications from research. International Journal of Science Education, 27(2), 183-198.

Çakır, A. ve Aydoğdu, B. (2016). Çevre sorunları konusunun öğretiminde karikatür kullanımının öğrencilerin akademik başarılarına ve çevreye yönelik tutumlarına etkisi. Batı Anadolu Eğitim Bilimleri Dergisi, 7 (14), $102-116$.

Çetin, E. (2012). Karikatürler ile zenginleştirilmiş fen ve teknoloji dersinin öğrenci başarısı ve tutumları üzerine etkisi. (Yayınlanmamış Yüksek lisans tezi), Selçuk Üniversitesi, Konya.

Eulie, J. (1969). Creating interest and developing understanding in social studies through cartoons. Peabody Journal of Education, 46(5), 288-290.

Evrekli, E. ve Balım, A. G. (2010). Fen ve teknoloji öğretiminde zihin haritası ve kavram karikatürü kullanımının öğrencilerin akademik başarıları ve sorgulayıcı öğrenme becerileri algılarına etkisi. Batı Anadolu Eğitim Bilimleri Dergisi. 1(2), 76-98. 
Ersoy, A. F. ve Türkkan, B. (2010). Illköğretim öğrencilerinin çizdikleri karikatürlere yansıttıkları sosyal ve çevresel sorunların incelenmesi. Eğitim ve Bilim, 35 (156), 96-109.

Gökkaya, K. (2006). İlköğretimde sosyal bilgiler öğretiminde karikatür kullanımı. (Yayımlanmamış yüksek lisans tezi), Gazi Üniversitesi Eğitim Bilimleri Enstitüsü, Ankara.

Hakam, J. (2009). Th e 'cartoons controversy': A critical discourse analysis of English language Arab newspaper discourse. Discourse \& Society, 20(1), 33-57.

İlikçi K. (2003).Toplumsal hafıza ve karikatür. http://www.nd-karikaturvakfi.org.tr/katalog2003.htm. (Erişim Tarihi: 5.7.2017).

İnel, D. ve Balım, A.G. (2011). Kavram karikatürleri destekli probleme dayalı öğrenme yönteminin ilköğretim 6.sınıf öğrencilerinin fen öğrenmeye yönelik motivasyonlarına etkisi. Uşak Üniversitesi Sosyal Bilimler Dergisi 4(1) 169- 188.

İnel, D. (2012). Kavram karikatürleri destekli problem dayalı öğrenme yönteminin öğrencilerin problem çözme becerileri algılarına, fen ögrenmelerine yönelik motivasyonlarına ve kavramsal anlama düzeylerine etkileri. (Yayınlanmamış doktora tezi). Dokuz Eylül Üniversitesi.

İngeç, Ş. K., Yıldız, İ. ve Ünlü, P. (2006). Identification of misconception about uniform circular motion by the use of concept cartoons, VII. National Science and Mathematics Education Conference, September 68, Ankara, Turkey.

Kabapınar, F. (2003). Oluşturmacı anlayışı yansıtması açısından Türk ve İngiliz fen bilgisi ve kimya ders kitaplarındaki görsel öğeler. Hacettepe Üniversitesi Eğitim Fakültesi Dergisi, 25, 119-126.

Keogh, B., Naylor, S., ve Wilson, C. (1998). Concept Cartoons: A New Perspective on Physics Education. Physics Education, 33(4), 219-224.

Keogh, B. ve Naylor, S. (1999). Concept cartoons, teaching and learning in science: an evaluation. International Journal of Science Education, 21(4), 431-446.

Kleeman, G. (2006). Using cartoons to investigate social and environmental issues. Ethos, 14(3), 9-19.

Kılınç, A. (2008). Öğretimde mizahi kavramaya dayalı Bir materyal geliştirme çalışması: Bilim karikatürleri (Yayınlanmamış Doktora Tezi). Gazi Üniversitesi, Ankara.

Köseoğlu, M. (2008). Tarih öğretimi açısından eleştirel düşünmede karikatür. 17. Ulusal Eğitim Bilimleri Kongresinde sunulan sözel bildiri, Sakarya.

Kuşakçı Ekim, F. (2007). Ilköğretim fen öğretiminde kavramsal karikatürlerin öğrencilerin kavram yanılgılarını gidermedeki etkisi (Yayınlanmamış Yüksek Lisans Tezi), Ankara Üniversitesi Eğitim Bilimleri Enstitüsü, Ankara.

Oluk, S. ve Özalp, I. (2007). Yapılandırmacı kurama göre küresel çevre sorunlarının öğretimi: problemin odak noktası olarak karikatürlerin kullanılabilirliği. Kuram ve Uygulamada Eğitim Bilimleri, 7 (2), 881 896.

Özalp, I. (2006). Karikatür tekniğinin fen ve çevre eğitiminde kullanılabilirliği üzerine bir araştırma. (Yayınlanmamış yüksek lisans tezi), Celal Bayar Üniversitesi, Manisa.

Özer, A. (2007). Karikatür ve eğitim. Bilim ve Aklın Aydınlığında Eğiti,. 84(7), 19-25.

Özşahin, E. (2009). Karikatürlerle coğrafya öğretimi. Marmara Coğrafya Dergisi, 20,101-122.

Morris, M., Merritt, M., Fairclough, S., Birrell, N. ve Howitt, C. (2007). Trialling concept cartoons in early childhood teaching and learning of science. Teaching Science. 53(2), 42-45. 
Rule A., C. ve Auge, J. (2005). Using humorous cartoons to teach mineral and rock concepts in six grade science class. Journal of Geoscience Education, 53(5), 548-558.

Seçkin, F., Gamze Y., G. ve Çetin, T. (2010) İlköğretim 8. Sınıf öğrencilerinin karikatürler aracılığıyla çevre sorunlarına ilişkin algıları. International Conference on New Trends in Education and Their Implications (Uluslararası Eğitimde ve uygulamalarında yeni trend konferansı).

Sidekli, S., Er, H., Yavaser, R. ve Aydin, E. (2014). Sosyal bilgiler ögretiminde alternative biryontem: Karikatur. Uluslar arasi Türk egitim bilimlerdergisi, 2(2), 151-163.

Stephenson, P. ve Warwick, P. (2002). Using concept cartoons to support progression in students' understanding of light. Physics Education, 37(2), 135-141.

Şengül, S. (2011). Effects of Concept Cartoons on Mathematics Self-Efficacy of 7th Grade Students, Kuram ve Uygulamada Egitim Bilimleri Educational Sciences: Theory\& Practice Autumn. 2305-2313.

Tashakkori, A. ve Teddlie, C. (1998). Mixed methodology: combining qualitative and quantitative modeles. London: Sage Publications.

Topçubaşı, T. ve Polat, S. (2014). Sosyal bilgiler öğretiminde kavram karikatürlerinin öğrenci başarısına etkisi. International Journal of New Trends in Arts, Sports \& Science Education, 3(2), 48-61.

Toprakcı, E. (2017) Sınıf Yönetimi. Ankara: Pegem Akademi Yayınları 3.Baskı

Uğurel, I. ve Moralı, S. (2006). Karikatürler ve matematik öğretiminde kullanımı. Milli Eğitim Dergisi, 35(170), 47-66.

Uslu, H. (2007). Eğitimde Karikatür. Bilim ve Aklın Aydınlığında Eğitim, 84(7), 15-18.

Üstün, Ö. (2007). Ortaöğretim üçüncü sınıfta Türk dili ve edebiyatı dersinde karikatür kullanımının yazılı anlatım öğretimine etkisi. Yayınlanmamış Yüksek Lisans Tezi. Çanakkale Onsekiz Mart Üniversitesi, Çanakkale. 


\title{
The Effect of Caricature Based Learning-Teaching Model on Pre-School Students' Speaking and Listening Skills
}

\author{
Dr. Sevda KOÇ AKRAN (Academician) \\ Siirt University-Turkey \\ sevdakc@gmail.com
}

\author{
inci KOCAMAN(MA) \\ Siirt University-Turkey \\ inci_ttanesi@hotmail.com
}

\begin{abstract}
The main purpose of this study is to determine the effect of caricature based learning -teaching model on pre-school students' speaking and listening skills. In the study where the dominant-less dominant mixed method design was used, the criterion sampling method from the objective sampling method was used. Semi-structured interview form and observation form developed by the researchers were applied to the study group. In the analysis of the data, the Shapiro-Wilks value was examined for the normal distribution of the materials in the observation form prepared for speaking and listening skills. Normality tests showed that the items on the observation form did not show normal distribution. The Mann Whitney U-Test was used to compare the scores of the students in the experimental and control groups, and the Wilcoxon Marked Rank test was used to compare the pre-test and post-test scores of the groups in the observation form prepared for the speaking and listening skills. Descriptive and content analysis methods were used in the data obtained from the semi-structured interview form. With the activities of the caricature based learning-teaching model, the result was reached that the students listened to their friends' activities and explanations carefully, that they did not understand these and asked questions about subjects they didn't understand and were curious about.
\end{abstract}

Keywords: Caricature, caricature based learning-teaching model, Speaking and Listening ability 


\section{EXTENDED ABSTRACT}

\section{Problem}

Caricature, an italian word, means exaggeration and overloading, amusing picture etc., and is a learning-teaching model, which finds an execution area in curriculums, in which modern modeles is used, and can be used in every age groups. With this model, individuals transfer their emotion and thoughts with amusing pictures. An individual sometime uses speaking, listening or other language skills during transfer procedures. Because the individual reacts by speaking about the reason why an object or event makes him/her laugh in the learning environment, or by listening to humorous incidents, which he/her heard or saw from others. Reactions of an individual reveal in accordance with his/her developmental characteristics. In other words, individuals in their first development periods are more interested in situations, which are more amusing and funnier for them and this case effects their speaking and listening skills significantly. In this study, it was tried to determine how the caricature-based learning-teaching model contributes to the children's skills in the pre-school period where speaking and listening skills improve significantly.

The main purpose of this study is to determine the effect of learning -teaching model to preschool students' speaking and listening skills. In accordance with this main objective, answers were seeked for the following questions:

1. Is there a significant difference between the points related to pre test-pos test speaking and listening skills of the experimental and control group?

2. Is there a significant difference between the points related to pos test speaking and listening skills of the experimental and control group?

3. The contribution, the caricature based learning-teaching model makes;

3.1 On students' speaking skills?

3.2 On students' listening skills?

\section{Method}

In the study where the dominant-less dominant mixed method design was used, the criterion sampling method from the objective sampling method was used. The criteria of children who took part within the research were that they should be five year old children who receive education in this pre-school which is centered to the Tatvan district of Bitlis. If the experiment group within the study group or the $g$ roup in which the researcher conducts the educationtraining process is a different pre-school it is determined a control group.

In the research, the activities of the teaching-learning model based on caricature are carried out, the observation form was be used in order to determine the skills of speaking and listening, "Cartoons in terms of meaning", "Humor, explanatory-illuminating cartoons and semi-structured observation form developed by the researchers. For the questions in the semi-structured interview form, the opinions of two teachers working in this field, two experts in the field of measurement and evaluation, education programs and teaching education, 6 preschool teachers and 2 Turkish teachers were applied. The necessary corrections have been made in accordance with the opinions of the experts. Besides, an observation form developed by the researchers was prepared in order to determine the contributions of caricature based learning-teaching model on students' speaking and listening skills. In addition to this, in the research, various caricature samples and activities were being cited through a document review.

In the analysis of the data, the Shapiro-Wilks value was examined for the normal distribution of the materials in the observation form prepared for speaking and listening skills. Normality tests 
showed that the items on the observation form did not show normal distribution. The Mann Whitney U-Test was used to compare the scores of the students in the experimental and control groups, and the Wilcoxon Marked Rank test was used to compare the pre-test and post-test scores of the groups in the observation form prepared for the speaking and listening skills. Descriptive and content analysis methods were used in the data obtained from the semistructured interview form.

\section{Results}

A differentiation was found in favor of the post-test in the scores of the experimental group on the pre-test-post-test speaking skills of the caricature based learning-teaching model. With the caricature based learning-teaching modeles activities of the students of the experimental group, the result was reached, that the students make short sentences, that they ask questions about pictures and objects they did not understand, that they express their thoughts in different ways etc.

With the activities of the caricature based learning-teaching model, the result was reached that the students listened to their friends' activities and explanations carefully, that they did not understand these and asked questions about subjects they didn't understand and were curious about.

There was no significant difference in the scores of the control group regarding pre-test and post-test speaking / listening skills.

With the activities conducted with caricature based learning-teaching model, questions were asked about what the students did not understand and the result was reached, that they can make various estimates, that they can ask questions about what they saw and while doing these, that they better understood the cause-and-effect relationship. The result is, that no change has taken place in the control group.

The experimental and control group scores for post-test listening skills differed in favor of the final test of the experimental group.

\section{Proposals}

1. The caricature based learning-teaching model was conducted on pre-school students. This model can be carried out on different class levels.

2. It can be explored, which student abilities the caricature-based learning-teaching model developed has developed.

3. The effect of the caricature based learning-teaching model on students' other language skills (reading, writing, listening and speaking) can be investigated. 